\title{
Managing the Psychological Contract During a Psychological Recession
}

\author{
Prof Paul Poisat \\ Nelson Mandela Metropolitan University \\ Email:Paul.Poisat@nmmu.ac.za
}

Anthonie Theron

Nelson Mandela Metropolitan University Email: Anthonie.Theron2@nmmu.ac.za

\section{Doi:10.5901/mjss.2014.v5n9p283}

\section{Abstract}

The aim of this study was to investigate the impact of Human Resource Management (HRM) practices on the psychological contracts of employees who have been negatively impacted by the widespread psychological recession. The prevalent economic recession has made it difficult for organisations to uphold their psychological contracts to employees, thereby contributing to a psychological recession - which is defined as an emotional state in which employees feel extremely vulnerable to economic hardship. The target population consisted of all permanent support staff working at an organisation that had recently experienced a large-scale retrenchment exercise $(n=52)$. A self-administered questionnaire was distributed amongst employees. The results, based on proven hypotheses, were summarised and depicted in a theoretical model. Inferential statistics suggest that the harsh effects and negative impact of the psychological recession may contribute to employees engaging in destructive work behaviour. A multiple regression analysis further emphasised the importance of HRM practices in maintaining a positive state of the psychological contract. Organisations have to respond to the psychological recession by carefully managing the employment relationship, and re-evaluating the effectiveness of their HRM actions and practices, in order to maintain the commitment and loyalty of their employees.

Keywords: HRM practices; psychological contract; psychological recession; economic recession; EVLN typology

\section{Introduction}

At present, the global economy is slowly recovering from one of its worst slumps in decades. In the current uncertain economic climate the employment relationship is being strained, especially with the continued threat of layoffs. Employees are thus less likely to be committed to their organisations when their relationship with the organisation is under threat. This relationship is referred to as the psychological contract, and is expressed as a structure of personal beliefs and attitudes regarding the shared obligations between an employee and his or her organisation (Knights and Kennedy, 2005).

In order for organisations to achieve desired performance objectives and goals, fulfilment of employees' psychological contracts is important. When these contracts are perceived to be unfulfilled or violated, it can lead to employees experiencing reduced organisational commitment, citizenship behaviour, counterproductive behaviour, and a stronger intention to quit or resign from their organisation (Brewster, Carey, Dowling, Grobler, Holland, and Wärnich, 2003). The current global economic downturn has arguably resulted in the development of a widespread psychological recession. This psychological recession is defined by Roche (2007) as an emotional vulnerability felt by employees in the face of economic hardship, leading to a negative and cynical view of the present; and a bleaker, less optimistic, view of the future.

The doom and gloom caused by the economic recession contributes to feelings of despair, as news of failing organisations and retrenchments manifests itself in employees being more stressed, anxious and less innovative at work. These behaviours all form part of a psychological recession (Bardwick, 2007).

The collective impact of a psychological recession, such as a reduction in organisational commitment and an increase in counterproductive behaviour of employees, can be devastating to an organisation. This leads to the question, how can organisations combat the negative impact caused by the psychological recession? This article proposes that, through the use and amplification of specific Human Resource Management (HRM) actions and practices, the negative 
impact of the psychological recession can be negated.

\section{Literature Review and Operationalisation of Variables}

The literature review is discussed according to the framework of the theoretical model. In figure 1, the selected factors influencing the dependent variables are depicted, namely, HRM practices and the psychological recession.

\subsection{Dependent variables}

\subsubsection{Psychological contract breach and violation}

The psychological contract refers to emotional relationship between the employee and the organisation. In other words, this relationship is defined what an employee owes to an organisation and what emotional assurances the employee can expect in return (Rousseau, 1989). An employee develops expectations regarding pay, job security, promotion, training, and support with personal problems. In return, the organisation expects the employee to work extra hours, volunteer on non-required tasks, be committed and protect company information (Knights \& Kennedy, 2005). However, organisations may not always be willing to fulfil all of the obligations made to their employees and this disparity results in a breach of the psychological contract (Pate, Martin and McGoldrick 2003).

The literature makes a clear distinction between the violation and breach of the psychological contract. On the one hand, according to Morrison and Robinson (1997), violation refers to the extreme emotional or affective reactions that accompany breaches. On the other hand, a breach, may be a relatively short-term incident, and could result in individuals returning to their relatively healthy psychological contract state, or alternatively, develop into full-blown violation (Pate, Martin and McGoldrick, 2003).

As psychological contract violation refers to the affective reactions that accompany breaches, the EVLN typology can be used to investigate potential responses when employees perceive that their psychological contracts have been violated. The EVLN framework suggests that employees respond to psychological contract breaches by increased exit (intention to quit), increased aggressive voice (efforts to win without considerations of the organisation), decreased loyalty (extra-role behaviours such as organisational citizenship behaviour), and increased neglect (absenteeism, lateness and less attention to quality) (Turnley and Feldman, 1999).

Another employee reaction to psychological contract breach includes decreased levels of organisational citizenship or extra-role behaviours (Conway and Briner, 2005). Perceived breach of the contract may have a negative impact on organisationally-focused citizenship behaviour (Robinson and Morrison, 1995). Employees perceive that the organisation has breached the psychological contract and thus will reciprocate by reducing their contributions to the organisation, in the form of reduced organisational citizenship behaviours (Robinson and Morrison, 1995). Given the above review of the literature, the following is hypothesised: or violated.

$\mathrm{H}_{1}$ : Employees may engage in destructive behaviours when their psychological contracts have been breached and

\subsection{Independent Variables}

\subsubsection{HRM practices}

It is widely held that HRM should be at the forefront of the creation, maintenance and protection of the psychological contract which develops between organisations and their employees (Rousseau and Greller, 1994). Pathak, Budhwar, Singh, and Hannas (2005) examined the impact of best HRM practices (BHRMP's) on employees' psychological outcomes. The results revealed that employees who enjoyed only a few BHRMP's reported lower levels of trust, fairness and delivery of promises from management, as well as a negative state of the psychological contract (Pathak, Budhwar, Singh, and Hannas, 2005).

According to Pfeffer (1998), BHRMP's include harmonisation, job security, sophisticated recruitment practices, sharing of performance and financial information, extensive training and development, empowered teams, and high compensation dependent on organisational performance. The employees' understanding of an organisation's HRM practices affect their assessment of the psychological contract.

In a recent study by Theron and Dodd (2011), an inverse relationship was found between the breach and the violation of the psychological contract, and the effective application of positive HRM practices. In short, the greater the 
number of positive HRM practices reported by respondents, the less breaches and violations of the psychological contract occurred (Theron and Dodd, 2011). Given the above, the following is hypothesised:

$\mathrm{H}_{2}$ : An increase in the number of positive HRM practices contributes to constructive employee behaviour.

$\mathrm{H}_{3}$ : The more positive HRM practices reported by respondents, the lower the negative impact of the psychological recession. practices.

$\mathrm{H}_{4}$ : The psychological contract is strengthened when there is a stronger presence and application of positive HRM

\subsubsection{The psychological recession}

Another cause of psychological contract breach is events occurring outside the organisation, which impacts the employee (Conway and Briner, 2005). The current global economic downturn, for instance, contributes to the creation of a psychological recession. According to Watson (2010), a psychological recession is much more than just an economic cycle. People who were retrenched due to intense cost-cutting may become depressed and anxious, and confidence and optimism are replaced by fear (Watson, 2010).

Labour market conditions in South Africa may exacerbate the effects of a psychological recession. According to the Quarterly Labour Force Survey conducted by Statistics South Africa (2012), the labour force decreased by 235000 persons between the third and forth quarter of 2012. A decrease in employment can be attributed to job losses experienced in the formal sector and private households. Discouraged work seekers increased by 87000 , while South Africa has experienced weak employment growth over the past two years. The largest decline in employment was observed in South Africa's Eastern Cape: they are where the current research study was conducted (Statistics South Africa, 2012).

A rise in the rates of unemployment will have an adverse effect on employee health and well-being. The risk of unemployment and perceived job insecurity results in intensification of employee stress (Tausig and Fenwick, 1999). Given the foregoing, the following is hypothesised:

$\mathrm{H}_{5}$ : The psychological recession contributes to breach and or violation of the psychological contract.

$\mathrm{H}_{6}$ : The psychological recession contributes to destructive employee behaviours.

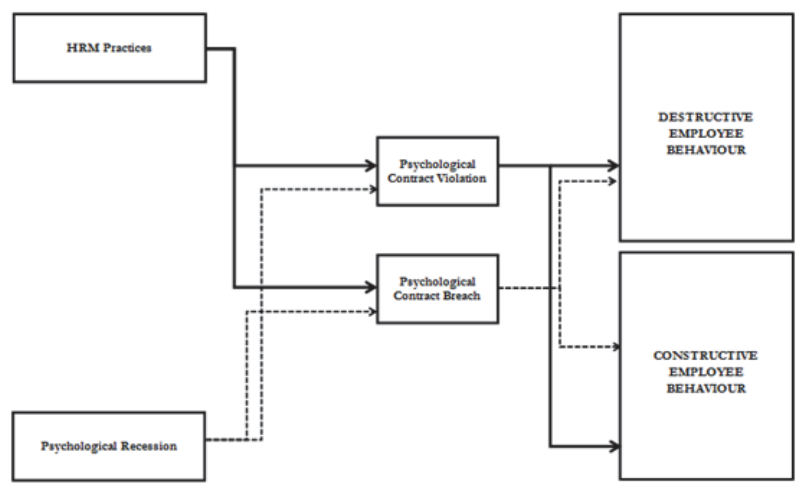

Figure 1. The Theoretical Model

\section{Research Methodology}

The study was conducted at a local poultry producer in the Eastern Cape Province that had recently undergone a major retrenchment. The organisation is South Africa's fourth largest poultry producer, and the conditions that contribute to a psychological recession, as discussed earlier, were deemed present. During 2010, poultry prices declined due to the Soccer World Cup, the stronger Rand, a substantial increase in imports, and an increase in national production. These factors led to an oversupply of poultry. The high cost of feed ingredients, electrical and other services-type costs and high import levels have been growing concerns for the organisation.

According to the Gauteng Enterprise Propeller (2010), dramatic increases in the price of feed have been the result of the consistently rising prices of maize and soya: the main raw materials in poultry feed. As these feed costs continue to 
increase, profit margins are getting smaller (Gauteng Enterprise Propeller, 2010). It is evident that the organisation has been severely impacted by the economic recession. During July 2010, the company embarked on an aggressive costcutting drive and retrenched a total of 34 Group Services employees as part of the exercise.

The organisation is separated into four profit centres in order to focus on margin realisation through both selling and producing the optimum product mix, as well as resolving costs, throughput and yield issues. These profit centres include the following:

- Manufacturing and Processing;

- Agriculture and Supply;

- Sales and Marketing; and

- Group Services.

The target subjects of this study consisted of all permanent support staff that was employed under the Group Services profit centre. According to payroll, the Group Services profit centre had a total staff headcount of 69 employees at the time of the survey. Permanent employees hold a different psychological contract with their organisation (Conway and Briner, 2005), and join an organisation with the expectation of developing a long and close relationship with it (McDonald and Makin, 2000). Thus, the implication is that violation has a greater impact on the attitudes and behaviour of permanently employed individuals.

\subsection{Measuring instrument}

The authors aimed to measure employees' perceptions of the psychological contract by focusing on the following constructs:

- The presence and application of positive HRM practices;

- Psychological contract breach and violation;

- Constructive and destructive employee behaviour. Considerate voice, patience and the five organisational citizenship behaviours (i.e. altruism, conscientiousness, sportsmanship, courtesy, and civic virtue) were measured as constructive employee behaviour. Exit, aggressive voice and neglect were measured as destructive employee behaviour; and

- The psychological recession.

A Likert-type rating scale with an unequal $1-5$ agreement format was selected for all the sections in the questionnaire. Closed format questions were used throughout the questionnaire. Validated scales from Guest and Conway (2004); Robinson and Morrison (2000); Hagedoorn, Van Yperen, Van de Vliert, and Buunk (1999); and Podsakoff, MacKenzie, Moorman, and Fetter (1990) were utilised to design a questionnaire that measured the abovementioned constructs.

\subsubsection{HRM practices}

The questionnaire utilised for this study incorporated the seven principal HRM practices that were used in the survey undertaken by the Chartered Institute of Personnel Development (CIPD) (Guest and Conway, 2004). Using a Likert-type rating scale with an unequal 1 - 5 agreement format, questions focused on the following aspects:

- The degree to which employees feel they have sufficient opportunities to express their views on issues and concerns at work;

- The degree to which employees feel that they are directly involved in activities designed to enable them to contribute to decision-making, and to make improvements at work;

- Whether employees have been offered training and development to update their skills in the past twelve months;

- Whether an employees' own personal performance have been assessed to their satisfaction during the past year;

- The extent to which employees believe that their employer tries to make their job as interesting and varied as possible;

- The extent to which employees believe that most vacancies are filled from within the organisation, a factor, which according to Guest and Conway (2004) is likely to enhance commitment and a greater inclination to stay with the organisation; and

- Whether individuals' pay is linked to their performance. 


\subsubsection{Psychological contract breach and violation}

Breach and violation were determined by looking at the work of Robinson and Morrison (2000). This measure focused on whether employees believe that their employer has kept their side of the contract through asking respondents about the extent to which their employer has fulfilled certain promises made to them (Conway and Briner, 2005). In order to measure violation, this section focused on emotional aspects such as betrayal, frustration and anger towards the organisation.

\subsubsection{The EVLN typology}

The Hagedoorn et al. (1999) modified EVLN instrument was utilised. Cronbach's coefficient alphas ranged from 0.69 to 0.92. With regards to concurrent validity, job satisfaction promoted considerate voice and patience, but suppressed aggressive voice, neglect and exit. The exit, neglect and aggressive voice responses have also proved to correlate with low perceived organisational justice (Liljegren, 2008). Respondents were given several descriptions of possible reactions to problematic events at work and were asked to indicate how likely it would be for them to react to problematic events in the described ways. Statements were rated on a five-point Likert scale.

\subsubsection{Organisational citizenship behaviour}

The organisational citizenship measure for the present study was developed by Podsakoff et al. (1990). This measure uses 24 items to describe the five dimensions of organisational citizenship behaviour. These include altruism, conscientiousness, sportsmanship, courtesy, and civic virtue. Coefficient alpha values ranged from 0.67 to 0.91 for altruism, 0.76 to 0.89 for sportsmanship, 0.69 to 0.86 for courtesy, and 0.66 to 0.90 for civic virtue. Coefficient alpha for conscientiousness was 0.79 . Coefficient alpha for the single organisational citizenship behaviour scale was 0.94 (Fields, 2002).

\subsubsection{The psychological recession}

For the psychological recession, items were formulated and rated on a five-point Likert scale in order to measure employees' perceptions around job security, job stability, South Africa's future, organisational change, and the trust between the employee and the organisation. Furthermore, employees were asked whether the organisation has retrenched people in the last two years, and whether they perceive the world as a risky place. Questionnaire items were formulated according to the theoretical definition of the psychological recession coined by Bardwick (2007).

\subsection{Data collection}

Questionnaires were disseminated door-to-door to the target population for completion. A cover letter explaining the procedure and instructions to complete the questionnaire was attached along with a return envelope. Respondents were instructed to put the completed questionnaire into the envelope. This method was time-consuming, but ensured more confidentiality, anonymity and a higher response rate, since certain questionnaire items contained sensitive wording, which may have tempered the response rate. A period of two weeks was allowed for completion of the questionnaire. This was to ensure that the questionnaires would not be forgotten in the midst of pressing business operations.

E-mail notifications were sent out to remind employees about the questionnaires and procedure for completion. According to Bickman and Rog (1998), a reminder is the single most important technique for producing high response rates. This has proven to be effective during the data collection phase.

52 completed questionnaires were returned and captured for analysis. This response rate of 75.3 per cent is acceptable within the scope of this investigation (De Lange, Bal, Van der Heijden, De Jong, and Schaufeli, 2011).

\subsection{Data analysis}

The reliability of the summated scores was determined by calculating Cronbach's coefficient alphas for the various sections of the questionnaire. 
Table 2. Cronbach's Coefficient Alphas $(n=52)$.

\begin{tabular}{|l|c|c|}
\hline QUESTIONNAIRE SECTION & CODE & CRONBACH'S COEFFICIENT ALPHA \\
\hline HRM Practices & FB & 0.81 \\
\hline Psychological Contract Breach & FC & 0.78 \\
\hline Psychological Contract Violation & FD & 0.95 \\
\hline Exit & FE.1 & 0.90 \\
\hline Considerate Voice & FE.2 & 0.94 \\
\hline Patience & FE.3 & 0.90 \\
\hline Aggressive Voice & FE.4 & 0.81 \\
\hline Neglect & FE.5 & 0.96 \\
\hline Altruism & FF.1 & 0.96 \\
\hline Conscientiousness & FF.2 & 0.91 \\
\hline Sportsmanship & FF.3 & 0.95 \\
\hline Courtesy & FF.4 & 0.97 \\
\hline Civic Virtue & FF.5 & 0.89 \\
\hline The Psychological Recession & FG & 0.88 \\
\hline
\end{tabular}

All scales had Cronbach's coefficient alphas above the threshold value of 0.7 , as seen on Table. 2, which, according to Nunally (1978), is sufficient proof of the reliability of the applicable scale scores whereas coefficient alphas above 0.5 can be regarded as acceptable for basic research. Table 3 shows the distribution of the demographic variables of the sample. The demographics of the sample drawn are a good representation of the organisation's demographics. The gender distribution reflects a normal trend where there are slightly more females (56\%) than males (44\%), which is reflective of data obtained from payroll.

The large proportion of Afrikaans speakers (50\%) denoted in Table 3 reflects the predominantly white and coloured composition of the organisation's demographics. With regards to the age distribution, Table 3 indicates that the vast majority of respondents range between the ages of 30 to 39 years (48\%). It is evident from Table 3 that the majority of the sample is skilled, as $33 \%$ of the sample forms part of the professional management cluster. A minority of the sample (2\%) formed part the unskilled staff cluster.

Table 3. Frequency distribution of the demographic variables of the sample $(n=52)$

\begin{tabular}{|c|c|c|}
\hline $\begin{array}{l}\text { DEMOGRAPHIC VARIABLE } \\
\text { GENDER }(n=52)\end{array}$ & FREQUENCY & PERCENTAGE \\
\hline Male & 23 & $44 \%$ \\
\hline Female & 29 & $56 \%$ \\
\hline Total & 52 & $100 \%$ \\
\hline \multicolumn{3}{|l|}{ HOME LANGUAGE ( $n=52)$} \\
\hline Afrikaans & 26 & $50 \%$ \\
\hline English & 18 & $35 \%$ \\
\hline Xhosa & 7 & $13 \%$ \\
\hline Other & 1 & $2 \%$ \\
\hline Total & 52 & $100 \%$ \\
\hline \multicolumn{3}{|l|}{ AGE $(n=52)$} \\
\hline 20 to 29 years & 11 & $21 \%$ \\
\hline 30 to 39 years & 25 & $48 \%$ \\
\hline 40 to 49 years & 11 & $21 \%$ \\
\hline 50 to 59 years & 5 & $10 \%$ \\
\hline Total & 52 & $100 \%$ \\
\hline \multicolumn{3}{|l|}{ SKILL LEVEL ( $n=52$ ) } \\
\hline Top Management & 1 & $2 \%$ \\
\hline Senior Management & 5 & $10 \%$ \\
\hline Professional Management & 17 & $33 \%$ \\
\hline Skilled Technician & 15 & $29 \%$ \\
\hline Semi-skilled & 13 & $25 \%$ \\
\hline Unskilled & 1 & $2 \%$ \\
\hline Total & 52 & $100 \%$ \\
\hline
\end{tabular}




\section{Results and Discussion}

Descriptive and inferential statistics were used for data analysis. The latter employed the statistical package STATISTICA, Version 11 (StatSoft, 2013). The results are discussed in light of the theoretical model and framework of the study.

\subsection{Descriptive statistics}

Table 4 shows the descriptive statistics for the various sections in the questionnaire. It was calculated that responses of between 1 and 2.6 on the Likert scale would fall into the "Low" category; between 2.6 and 3.4 in the "Average" category; and between 3.4 and 5 in the "High" category. The major contributors to the mean scores listed in Table 4 will be discussed.

Table 4: Descriptive statistics for all variables $(n=52)$

\begin{tabular}{|c|c|c|c|c|c|c|c|c|c|}
\hline FACTORS & MEAN & S.D. & MEDIAN & \multicolumn{2}{|c|}{$\begin{array}{c}\text { LOW } \\
{[1.0 \text { to } 2.6)}\end{array}$} & \multicolumn{2}{|c|}{$\begin{array}{l}\text { MEDIUM } \\
\text { [2.6 to } 3.4 \text { ] }\end{array}$} & \multicolumn{2}{|c|}{$\begin{array}{c}\text { HIGH } \\
\text { (3.4 to } 5.0]\end{array}$} \\
\hline HRM Practices & 2.51 & 0.75 & 2.57 & 29 & $56 \%$ & 14 & $27 \%$ & 9 & $17 \%$ \\
\hline Psychological Contract Breach & 3.21 & 0.89 & 3.40 & 14 & $27 \%$ & 18 & $35 \%$ & 20 & $38 \%$ \\
\hline Psychological Contract Violation & 2.86 & 1.18 & 3.13 & 19 & $37 \%$ & 9 & $17 \%$ & 24 & $46 \%$ \\
\hline Exit & 3.25 & 0.96 & 3.50 & 13 & $25 \%$ & 12 & $23 \%$ & 27 & $52 \%$ \\
\hline Considerate Voice & 3.35 & 0.81 & 3.50 & 10 & $19 \%$ & 13 & $25 \%$ & 29 & $56 \%$ \\
\hline Patience & 2.55 & 0.91 & 2.70 & 24 & $46 \%$ & 20 & $38 \%$ & 8 & $15 \%$ \\
\hline Aggressive Voice & 3.03 & 0.77 & 3.00 & 15 & $29 \%$ & 16 & $31 \%$ & 21 & $40 \%$ \\
\hline Neglect & 2.55 & 1.20 & 2.80 & 25 & $48 \%$ & 9 & $17 \%$ & 18 & $35 \%$ \\
\hline Altruism & 3.55 & 1.14 & 3.80 & 9 & $17 \%$ & 9 & $17 \%$ & 34 & $65 \%$ \\
\hline Conscientiousness & 3.85 & 0.84 & 3.80 & 4 & $8 \%$ & 11 & $21 \%$ & 37 & $71 \%$ \\
\hline Sportsmanship & 3.88 & 0.93 & 4.00 & 7 & $13 \%$ & 6 & $12 \%$ & 39 & $75 \%$ \\
\hline Courtesy & 3.63 & 0.98 & 4.00 & 7 & $13 \%$ & 15 & $29 \%$ & 30 & $58 \%$ \\
\hline Civic Virtue & 3.26 & 0.84 & 3.25 & 12 & $23 \%$ & 16 & $31 \%$ & 24 & $46 \%$ \\
\hline The Psychological Recession & 3.48 & 0.75 & 3.60 & 6 & $12 \%$ & 16 & $31 \%$ & 30 & $58 \%$ \\
\hline
\end{tabular}

\subsubsection{HRM practices}

The application and presence of positive HRM practices were found to be of concern. For training and development initiatives, 50 per cent of respondents revealed that they have not been offered training and development, where only 33 per cent of respondents have been offered developmental opportunities to update their skills. This low percentage may be due to inadequate performance appraisal and management practices. 54 per cent of respondents felt that their performance has not been evaluated adequately during the previous year. Developmental needs and performance objectives are identified during the performance appraisal process (Grobler, Wärnich, Carrel, Elbert and Hatfield, 2006).

For workplace involvement and empowerment practices, 63 per cent of the sample indicated that they have not been personally involved in such practices. With regards to performance-related pay practices, the majority of the sample indicated that their pay is not related to their personal performance (65\%). The results indicate that the organisation does not employ many HRM practices and activities, which may result in psychological contract breach and violation.

\subsubsection{Psychological contract breach}

The results indicated that respondents' psychological contracts have been breached. 54 per cent of the sample felt that their employer has not fulfilled the promises made to them when they were hired. With regards to promises that were made during the recruitment and selection stage, 60 per cent of the sample indicated that almost no promises have been kept. According to Aggarval, Datta and Bhargava (2007), literature indicates that recruiters tend to depict jobs in more positive, auspicious and favourable terms. Chances of psychological contracts being violated are therefore high as many of the expectations are set unrealistically high. 


\subsubsection{Psychological contract violation}

The majority of the sample (52\%) indicated that they felt frustrated by the way they have been treated within their organisation. Most respondents (39\%) also felt that the organisation had violated the psychological contract between them.

\subsubsection{Destructive employee behaviour: Exit, aggressive voice and neglect}

There seems to be strong exit behaviour directed towards the organisation, as the majority of the sample (55\%) indicated that they are perusing job advertisements in newspapers and similar mediums for application opportunities. Fifty-one per cent of the sample indicated that they are considering the possibility of changing jobs. With regards to aggressive voice, the results indicated strong aggressive voice behaviour towards the organisation. The majority of the sample (44\%) blames the company for the problem, with 50 per cent of the sample trying to win the case and prove beyond a shadow of a doubt that they are right.

As neglect refers to employees who are passively allowing working conditions to worsen and deteriorate, 42 per cent of the sample indicated that they would not attend meetings, because they "do not feel like attending them", where another 42 per cent of the sample would not put enough effort into their work. With regards to absenteeism, 31 per cent of the sample indicated that they would report in sick as they "do not feel like working".

\subsubsection{Constructive employee behaviour: Considerate voice, patience and organisational citizenship behaviour}

With regards to considerate voice, employees seem to actively make attempts to solve the problem when responding to problematic events at work, whilst considering their own interests including those of the organisation. The majority of the sample indicated that they would try to come to an understanding with their manager (58\%), and think of different solutions to the problem (59\%), when responding to problematic events at work. As for patience, half of all respondents were not likely to have faith that the organisation will take care of the problem. The results indicated that employees were not likely to optimistically wait for conditions to improve at work. With regards to organisational citizenship behaviour, employees seem to engage in altruistic behaviour that fall outside their normal job descriptions.

Furthermore, the results indicate that respondents are actively conscientious at work and try to prevent possible conflict escalation and interpersonal conflict at work. Interestingly, respondents seem to not actively engage in sportsmanship behaviour. The results indicate that the majority of the sample does not show tolerance of inevitable problems and inconveniences that may be part of their job. A major 76 per cent of the sample indicated that they tend to make "mountains out of molehills", where 77 per cent of the sample consume a lot of time complaining about unimportant matters at work. Significantly, respondents chose to be mostly neutral about items pertaining to the civic virtue subscale.

\subsubsection{The psychological recession}

The results show that employees have been negatively impacted by the psychological recession, which places strain on the employment relationship. With regards to retrenchments and layoffs at work, a major 88 per cent of the sample indicated that the organisation has retrenched employees in the last two years. The majority of the sample also indicated that they feel depressed when hearing about all the negative things currently taking place in the world, where 59 per cent of respondents feel anxious due to the economic recession.

More than half of the respondents (54\%) indicated that they do not trust their organisation to look after their interests.

\subsection{Inferential statistics}

This section provides a discussion of the inferential statistics obtained from the research study.

\subsubsection{Hypotheses testing}

Pearson product-moment correlations were calculated to measure the degree and direction of the relationships depicted in the hypotheses. Correlation coefficients greater than $0.273(r>0.273)$ are statistically significant, where coefficients greater than 0.300 are practically significant $(r>0.300)$. Tables 5 and 6 show the Pearson product-moment correlation 
coefficients for the summated scores. For layout purposes, the correlation matrix was split into two separate tables.

\subsubsection{1 $H_{1}$ : Employees may engage in destructive behaviours when their psychological contracts have been breached and or violated.}

The findings provide support for hypothesis one. With regards to psychological contract breach and constructive employee behaviour, the results show that when respondents indicated that their psychological contracts have been breached, constructive behaviour at work decreased. Employees may be less likely to engage in constructive behaviour at work, as inverse relationships were found between psychological contract breach and considerate voice $(-0.423)$, patience $(-0.541)$, altruism $(-0.371)$, conscientiousness $(-0.494)$, sportsmanship $(-0.375)$, courtesy $(-0.249)$, and civic virtue $(-0.409)$.

Inverse relationships were also found between psychological contract violation and considerate voice $(-0.566)$, patience $(-0.639)$, altruism $(-0.506)$, conscientiousness $(-0.627)$, sportsmanship $(-0.481)$, courtesy $(-0.452)$, and civic virtue $(-0.518)$. With regards to psychological contract breach and destructive employee behaviour, the results indicate positive correlations between breach and exit (0.504), aggressive voice (0.574) and neglect (0.494).

The findings suggest that when psychological contracts are breached, employees may have a greater tendency to engage in destructive behaviour at work, such as leaving the organisation (exit), engage in efforts to win without consideration for the concerns of the organisation (aggressive voice), and passively allowing working conditions to deteriorate (neglect). Positive correlations were also found between psychological contract violation and exit (0.685), aggressive voice (0.673) and neglect (0.694).

\subsubsection{2 $\mathrm{H}_{2}$ : An increase in the number of positive HRM practices contributes to constructive employee behaviour.}

Hypothesis two is supported. With regards to constructive employee behaviour, the results show a positive relationship between HRM practices and considerate voice $(0.590)$, patience $(0.662)$, altruism $(0.493)$, conscientiousness $(0.442)$, sportsmanship (0.320), courtesy, (0.285), and civic virtue (0.406). This indicates that an increase in the number of HRM practices reported by respondents correlated with an increase in constructive employee behaviour. The findings may suggest that when positive HRM practices are applied at work, employees may have a greater tendency to engage in constructive employee behaviour.

With regards to destructive employee behaviour, the results present an inverse relationship between the number of HRM practices reported by respondents as evidenced by employee exit $(-0.620)$, aggressive voice $(-0.638)$ and neglect (0.545).

In short, an increase in HRM practices reported by respondents correlated with a decrease in destructive employee behaviour. The findings suggest that when employees enjoy a greater number and presence of positive HRM practices, they may have a greater tendency to not engage in destructive behaviour at work.

\subsubsection{3 $\mathrm{H}_{3}$ : The more positive HRM practices reported by respondents, the lower the negative impact of the psychological recession.}

The findings provide support for hypothesis three. The results indicate an inverse relationship between HRM practices and the psychological recession (-0.520). It can be argued that with an increase in the number of positive HRM practices, the less harsh the negative impact of the psychological recession on employees. The findings suggest that the negative impact of the psychological recession may be reduced due to the presence and effective application of HRM practices.

\subsubsection{4 $\mathrm{H}_{4}$ : The psychological contract is strengthened when there is a stronger presence and application of positive HRM practices.}

The results indicate that there is an inverse relationship between HRM practices and psychological contract breach ($0.770)$, including violation (-0.682). It can be said that with the increase in the number of HRM practices reported by respondents, the less the breach and violation of the psychological contract. The presence and thorough application of positive HRM practices may strengthen the psychological contract, by making the employment relationship less prone to breach and violation. 


\subsubsection{5 $H_{5}$ : The psychological recession contributes to breach and or violation of the psychological contract.}

Hypothesis five is supported. An encouraging correlation was discovered between the psychological recession and psychological contract violation $(0.645)$ and breach $(0.474)$. The results indicate that the more negative and harsh the impact of the psychological recession, the more breach and violation were reported by respondents. It is evident that the psychological contract becomes more fragile in an environment where employees feel anxious, stressed, depressed, insecure about their jobs, and vulnerable.

\subsubsection{6 $H_{6}$ : The psychological recession contributes to destructive employee behaviours.}

With regards to constructive employee behaviour, the results indicate an inverse relationship between the psychological recession and considerate voice $(-0.471)$, including patience $(-0.475)$. To clarify, the findings suggest that employees may be less likely to optimistically wait for conditions at work to improve (patience), and actively make attempts to solve workrelated problems, while considering their own concerns as well as those of the organisation (considerate voice). Regarding organisational citizenship behaviour, the results indicate an inverse relationship between the psychological recession and altruism $(-0.420)$, conscientiousness $(-0.541)$, sportsmanship $(-0.471)$, courtesy $(-0.385)$, and civic virtue (0.450).

Table 5. Pearson product-moment correlations for the summated scores $(n=52)$.

\begin{tabular}{|c|c|c|c|c|c|c|c|}
\hline |ITEM & HRM PRACTICES & BREACH & VIOLATION & EXIT & CONSIDERATE VOICE & |PATIENCE & AGGRESSIVE VOICE \\
\hline HRM PRACTICES & & -0.770 & -0.682 & -0.620 & 0.590 & 0.662 & -0.638 \\
\hline BREACH & -0.770 & & 0.691 & 0.504 & -0.423 & -0.541 & 0.574 \\
\hline VIOLATION & -0.682 & 0.691 & & 0.685 & -0.566 & -0.639 & 0.673 \\
\hline EXIT & -0.620 & 0.504 & 0.685 & & -0.689 & -0.667 & 0.707 \\
\hline CONSIDERATE VOICE & 0.590 & -0.423 & -0.566 & -0.689 & & 0.677 & -0.587 \\
\hline |PATIENCE & 0.662 & -0.541 & -0.639 & -0.667 & 0.677 & & -0.637 \\
\hline AGGRESSIVE VOICE & -0.638 & 0.574 & 0.673 & 0.707 & -0.587 & -0.637 & \\
\hline NEGLECT & -0.545 & 0.494 & 0.694 & 0.748 & -0.535 & -0.558 & 0.755 \\
\hline ALTRUISM & 0.493 & -0.371 & -0.506 & -0.536 & 0.620 & 0.477 & -0.521 \\
\hline CONSCIENTIOUSNESS & 0.442 & -0.494 & -0.627 & -0.518 & 0.446 & 0.485 & -0.540 \\
\hline SPORTSMANSHIP & 0.320 & -0.375 & -0.481 & -0.444 & 0.378 & 0.480 & -0.498 \\
\hline COURTESY & 0.285 & -0.249 & -0.452 & -0.376 & 0.235 & 0.268 & -0.502 \\
\hline CIVIC VIRTUE & 0.406 & -0.409 & -0.518 & -0.539 & 0.391 & 0.407 & -0.520 \\
\hline PSYCHOLOGICAL RECESSION & -0.520 & 0.474 & 0.645 & 0.620 & -0.471 & -0.475 & 0.628 \\
\hline
\end{tabular}

Table 6. Pearson product- moment correlations for the summated scores $(n=52)$.

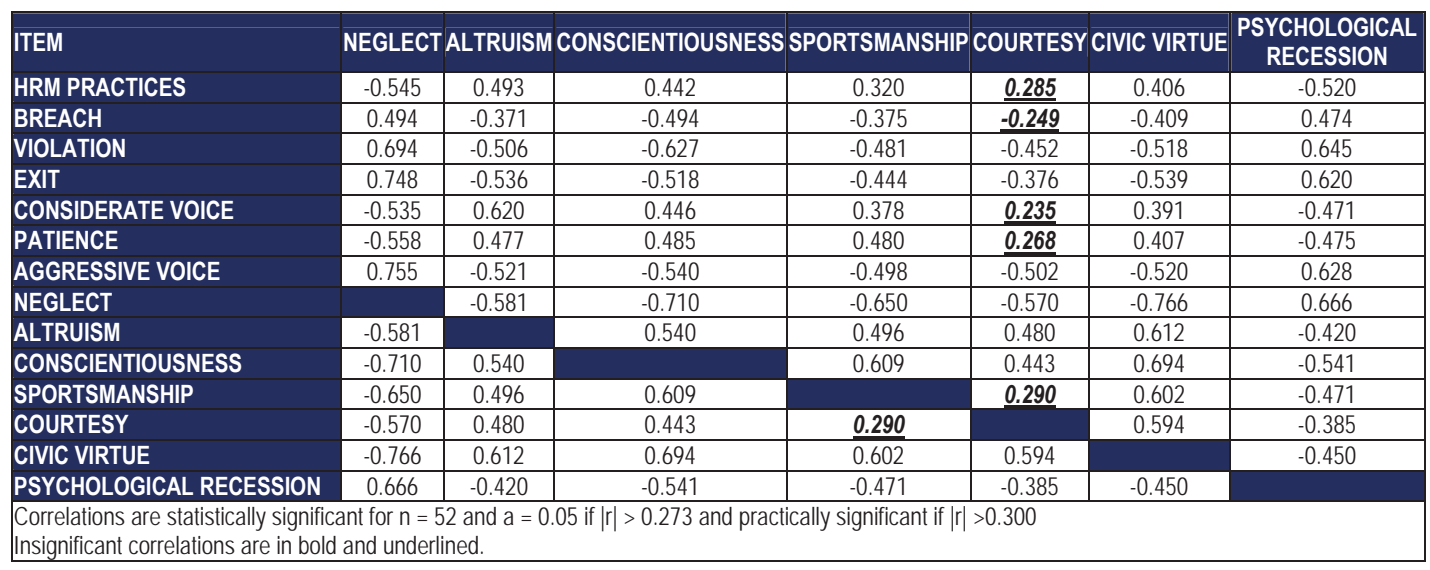

To summarise this section, the findings suggest that the harsher the negative effects of the psychological recession, the 
less likely employees would engage in constructive behaviour at work. With regards to destructive employee behaviour, the findings indicate a positive correlation between the psychological recession and employee exit $(0.620)$, aggressive voice (0.628) and neglect (0.666). In other words, as the harsh effects and negative impact of the psychological recession increase, destructive employee behaviour increases. The findings may suggest that due to the psychological recession, employees may be more inclined to terminate their relationship with their organisation, engage in efforts to win (without consideration for the organisation), and passively allow working conditions to worsen and deteriorate.

\subsubsection{Multiple regression analysis}

A multiple regression analysis was conducted to further investigate the relationships depicted in the theoretical model. The standardised regression coefficient $\left(b^{*}\right)$ indicates the effect of the independent variable on the dependent variable, while keeping the other independent variable fixed. Unstandardized regression coefficients (b) are also listed in the regression summaries.

Table 7. Regression summary for dependent variable: Psychological contract violation.

\begin{tabular}{|l|c|c|c|c|}
\hline VARIABLE & $\mathbf{b}^{*}$ & Standard error of $\mathbf{b}^{*}$ & $\mathbf{b}$ & $\mathbf{p}$-value \\
\hline Intercept & & & 2.538 & 0.0071 \\
\hline HRM Practices & -0.475 & 0.108 & -0.745 & 0.0001 \\
\hline Psychological Recession & 0.398 & 0.108 & 0.629 & 0.0006 \\
\hline $\begin{array}{l}\mathbf{R}=0.76 ; \mathbf{R}^{2}=\mathbf{0 . 5 8} \\
\text { Insignificant correlations are in bold and underlined. }\end{array}$ \\
\hline
\end{tabular}

As shown in Table 7, the psychological recession was significantly related to violation of the psychological contract (0.398). The results provide strong support for hypothesis five, which proposes that the psychological contract may become more fragile during a psychological recession. Hypothesis four predicted that the psychological contract may be strengthened when there is a stronger presence and application of HRM practices. This relationship was further supported, as a significant inverse relationship was found between HRM practices and psychological contract violation (0.475).

Table 8. Regression summary for dependent variable: Psychological contract breach.

\begin{tabular}{|l|c|c|c|c|}
\hline VARIABLE & $\mathbf{b}^{*}$ & Standard error of $\mathbf{~ b}^{*}$ & $\mathbf{b}$ & $\mathbf{p}$-value \\
\hline Intercept & & & 4.914 & 0.0000 \\
\hline HRM Practices & -0.717 & 0.106 & -0.846 & 0.0000 \\
\hline Psychological Recession & $\underline{\mathbf{0 . 1 0 1}}$ & $\underline{\mathbf{0 . 1 0 6}}$ & $\underline{\mathbf{0 . 1 2 0}}$ & $\underline{\mathbf{0 . 3 4 4 3}}$ \\
\hline $\begin{array}{l}\mathrm{R}=\mathbf{0 . 7 7} ; \mathbf{R}^{2}=\mathbf{0 . 6 0} \\
\text { Insignificant correlations are in bold and underlined. }\end{array}$ \\
\hline
\end{tabular}

Interestingly, Table 8 shows an insignificant positive relationship between the psychological recession and breach of the psychological contract (0.101). As mentioned above, breach is essentially the identification of perceived unmet obligations (Pate, Martin and McGoldrick, 2003) and violation refers to the extreme affective reactions that accompany breaches (Morrison and Robinson, 1997).

Based on the descriptive statistics of the study, all respondents included in the analysis experienced some degree of breach. However, the descriptive statistics indicated a stronger presence of violation in respondents' psychological contracts, as 52 per cent of respondents felt frustrated and unfulfilled by how they have been treated by the organisation.

Table 8 further shows that HRM practices are significantly inversely related to breach of the psychological contract $(-0.717)$. This provides strong support for hypothesis four, which stressed the importance of HRM practices in maintaining a positive state of the psychological contract. Organisations need to respond to the psychological recession by carefully managing the employment relationship and re-evaluating the effectiveness of their current HRM practices. When employees are recruited, when their performance is appraised, and when they see value in their compensation packages, or receive positive recognition for their efforts, employees interpret the experience, and that interpretation will determine the employee's perception of the psychological contract (Aggarval, Datta and Bhargava, 2007). 
Table 9. Regression summary for destructive employee behaviour: Exit, aggressive voice and neglect.

\begin{tabular}{|c|c|c|c|c|}
\hline \multicolumn{5}{|c|}{ Regression summary for dependent variable: Exit } \\
\hline VARIABLE & $\mathbf{b}^{*}$ & Standard error of $b^{*}$ & b & p-value \\
\hline Intercept & & & 1.554 & 0.0001 \\
\hline Psychological Contract Breach & 0.057 & 0.144 & 0.062 & 0.6914 \\
\hline Psychological Contract Violation & 0.645 & 0.144 & 0.523 & 0.0000 \\
\hline \multicolumn{5}{|l|}{$R=0.69 ; R^{2}=0.47$} \\
\hline \multicolumn{5}{|c|}{ Regression summary for dependent variable: Aggressive voice } \\
\hline VARIABLE & $\mathbf{b}^{*}$ & Standard error of $b^{*}$ & b & p-value \\
\hline Intercept & & & 1.460 & 0.0000 \\
\hline Psychological Contract Breach & 0.208 & 0.143 & 0.180 & 0.1535 \\
\hline Psychological Contract Violation & $\overline{0.530}$ & $\overline{0.143}$ & $\overline{0.346}$ & $\overline{0.0005}$ \\
\hline \multicolumn{5}{|l|}{$R=0.69 ; R^{2}=0.48$} \\
\hline \multicolumn{5}{|c|}{ Regression summary for dependent variable: Neglect } \\
\hline VARIABLE & $\mathbf{b}^{*}$ & Standard error of $\mathbf{b}^{*}$ & b & p-value \\
\hline Intercept & & & 0.455 & 0.3322 \\
\hline Psychological Contract Breach & 0.026 & 0.142 & $\overline{0.036}$ & $\overline{0.8537}$ \\
\hline Psychological Contract Violation & 0.676 & 0.142 & 0.691 & 0.0000 \\
\hline \multicolumn{5}{|c|}{$\begin{array}{l}\mathbf{R}=0.69 ; \mathbf{R}^{2}=0.48 \\
\text { Insignificant correlations are in bold and underlined. }\end{array}$} \\
\hline
\end{tabular}

The theoretical model shows that employees may respond to psychological contract breaches by engaging in various destructive behaviours at work. The present study investigated exit, aggressive voice, and neglect as part of destructive behaviour. Table 9 shows that violation had significant regression coefficients for exit $(0.645)$, aggressive voice (0.530) and neglect (0.676). The findings provide additional support for hypothesis one, which predicted that employees may engage in destructive behaviours when their psychological contracts have been violated. Interestingly, psychological contract breach was not significantly related to exit (0.057), aggressive voice (0.208) and neglect $(0.026)$.

Table 10. Regression summary for constructive employee behaviour: Considerate voice and patience.

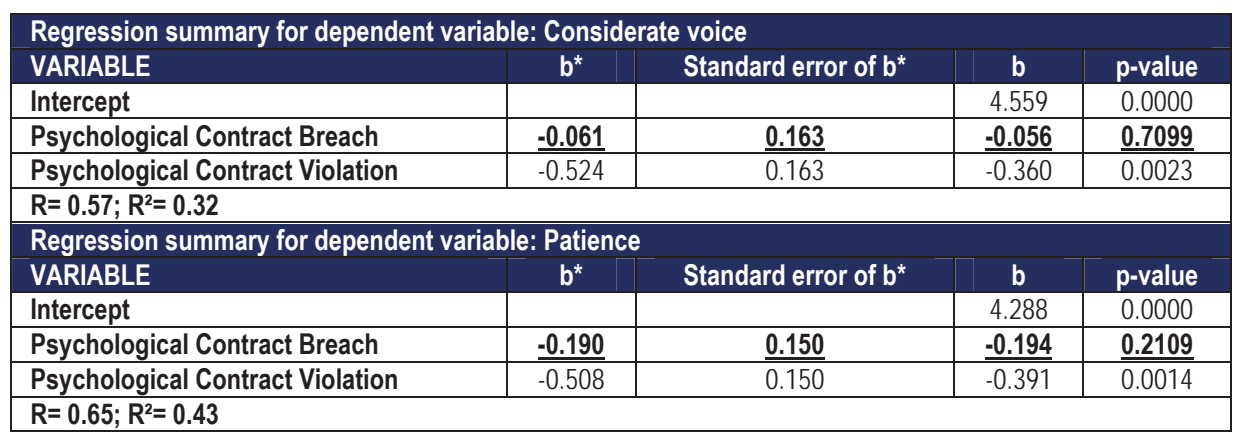

The present study investigated considerate voice, patience and the five organisational citizenship behaviours as part of constructive employee behaviour. According to Table 10, violation was also significantly related to considerate voice ($0.524)$ and patience (-0.508).

Table 11. Regression summary for constructive employee behaviour: Organisational citizenship behaviour.

\begin{tabular}{|c|c|c|c|c|}
\hline \multicolumn{5}{|c|}{ Regression summary for dependent variable: Altruism } \\
\hline VARIABLE & $\mathbf{b}^{*}$ & Standard error of $b^{*}$ & b & p-value \\
\hline Intercept & & & 5.039 & 0.0000 \\
\hline Psychological Contract Breach & -0.040 & $\underline{0.170}$ & $\underline{-0.052}$ & $\underline{0.8149}$ \\
\hline Psychological Contract Violation & -0.479 & 0.170 & -0.463 & $\overline{0.0071}$ \\
\hline
\end{tabular}




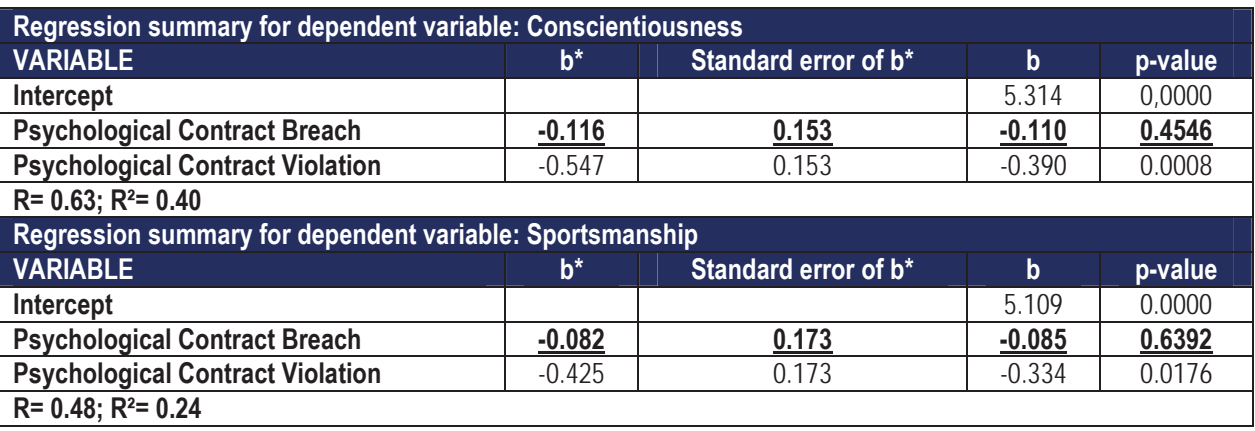

\begin{tabular}{|c|c|c|c|c|}
\hline \multicolumn{5}{|c|}{ Regression summary for dependent variable: Courtesy } \\
\hline VARIABLE & $\mathbf{b}^{*}$ & Standard error of $b^{*}$ & b & p-value \\
\hline Intercept & & & 4.479 & 0.0000 \\
\hline Psychological Contract Breach & 0.122 & 0.176 & $\underline{0.135}$ & 0.4914 \\
\hline Psychological Contract Violation & -0.536 & 0.176 & -0.447 & 0.0037 \\
\hline \multicolumn{5}{|l|}{$R=0.46 ; R^{2}=0.21$} \\
\hline \multicolumn{5}{|c|}{ Regression summary for dependent variable: Civic virtue } \\
\hline VARIABLE & $\mathbf{b}^{*}$ & Standard error of $b^{*}$ & b & p-value \\
\hline Intercept & & & 4.477 & 0.0000 \\
\hline Psychological Contract Breach & -0.098 & 0.169 & -0.093 & 0.5624 \\
\hline Psychological Contract Violation & -0.450 & $\overline{0.169}$ & -0.319 & $\overline{0.0104}$ \\
\hline
\end{tabular}

Table 11 indicates that psychological contract violation also showed significant regression coefficients for the five organisational citizenship behaviours namely altruism $(-0.479)$, conscientiousness $(-0.547)$, sportsmanship $(-0.425)$, courtesy $(-0.536)$, and civic virtue $(-0.450)$. These findings provide additional support for hypothesis one.

\section{Conclusion, Recommendations and Implications for Managers}

This study highlighted the practical importance of HRM practices in maintaining fulfilment of employees' psychological contracts during a psychological recession. The present study suggests that psychological contract breach and violation can be reduced when organisations are actively paying attention to the psychological contract, by developing and applying various positive HRM activities and practices. Sonnenberg (2006) supports this by stating that organisations should actively pay attention to managing the psychological contract through various HRM interventions and practices. HRM practices may help employees to develop expectations of their employment relationship, which safeguard them against disappointments (Sonnenberg, 2006). High impact HRM practices such as recognition, employee value proposition (EVP), empowerment, engagement and information sharing practices were found to contribute positively to the psychological contract and negate the impact of the psychological recession.

The negative consequences caused by repeated breach of the psychological contract are likely to remain widespread in organisations as long as the psychological recession continues. If the psychological recession continues to be part of organisational life, then the challenge for managers is to learn to successfully navigate through and control the psychological recession in a way that protects employees' sense of trust and psychological contract. Of course, as with most research, this study is subject to a number of potential limitations. The outcomes of the present study may not be able to be readily applied to other organisations, since management practices and the organisational culture will differ between them. The sample for the present study only included permanent and higher-level staff members. The research could be expanded to include temporary staff and lower-level employees. It is also recommended that more research be done to identify specific HRM practices that may be of value to employees during a psychological recession. Furthermore, although a sample size of 52 is adequate for statistical analysis, caution must be exercised in expanding these findings beyond the related hypotheses. The results of this study should be interpreted in terms of the limitations. The authors hope that future research may replicate the current findings in various contract forms, organisations and countries. 


\section{References}

Aggarval, U., Datta, S. and Bhargava, S. (2007). The Relationship between Human Resource Practices, Psychological Contract and Employee Engagement - Implications for Managing Talent. IIMB Management Review, 19(3), 313-325.

Bardwick, J.M. (2007). One Foot Out the Door: How to Combat the Psychological Recession That's Alienating Employees and Hurting American Business. New York: Amacom.

Bickman, L. and Rog, D.J. (1998). Handbook of Applied Social Research Methods. Thousand Oaks, California: Sage.

Brewster, C., Carey, L., Dowling, P.J., Grobler, P.A., Holland, P. and Wärnich, S. (2003). Contemporary Issues in Human Resource Management. $2^{\text {nd }}$ ed. Cape Town: Oxford University Press.

Conway, N. and Briner, R.B. (2005). Understanding Psychological Contracts at Work: A Critical Evaluation of Theory and Research. Oxford: Oxford University Press.

De Lange, A. H., Bal, P. M., Van der Heijden, B. I.J.M., de Jong, N. and Schaufeli, W. B. (2011). When I'm 64: Psychological contract breach, work motivation and the moderating roles of future time perspective and regulatory focus. Work \& Stress: An International Journal of Work, Health \& Organisation, 25(4), 338-354.

Fields, D.L. (2002). Taking the Measure of Work: A Guide to Validated Scales for Organizational Research and Diagnosis. Thousand Oaks: Sage.

Gauteng Enterprise Propeller. (2010). SA Market Summaries: Poultry and Egg Production. [Online] Available: http://gep.cobwebinfo.co.za /servlet/file/SAMS\%20019\%20Poultry\%20and\%20egg\%20production\%20-GEP\%20-\%20print.pdf?item_ent_id=14233\&item_coll _schema_id=407\&item_version=1 (September 23, 2011).

Grobler, P., Wärnich, S., Carrel, M.R., Elbert, N.F. and Hatfield, R.D. (2006). Human Resource Management in South Africa. (3rd ed.). Croatia: Thomson Learning.

Guest, D.E. and Conway, N. (2004). Employee Well-Being and the Psychological Contract: A Report for the CIPD. London: CIPD.

Hagedoorn, M., Van Yperen, N.W., Van de Vliert, E. and Buunk, B.P. (1999). Employees' reactions to problematic events: A circumplex structure of five categories of responses, and the role of job satisfaction. Journal of Organizational Behavior, 26(20), 309-321.

Knights, J.A. and Kennedy, B.J. (2005). Psychological Contract Violation: Impacts on Job Satisfaction and Organizational Commitment Among Australian Senior Public Servants. Applied H.R.M. Research, 10(2), 57-72.

Liljegren, M. (2008). Health at Work: The Relationship between Organisational Justice, Behavioural Responses, and Health. PhD. Linkoping University.

McDonald, D.J. and Makin, P.J. (2000). The psychological contract, organisational commitment and job satisfaction of temporary staff. Leadership and Organization Development Journal, 21(2), 84-91.

Morrison, E.W. and Robinson, S.L. (1997). When Employees Feel Betrayed: A Model of How Psychological Contract Violation Develops. The Academy of Management Review, 22(1), 226-256.

Nunally, J. (1978). Psychometric Theory. 2nd ed. New York: McGraw-Hill.

Pate, J., Martin, G. and McGoldrick, J. (2003). The Impact of Psychological Contract Violation on Employee Attitudes and Behaviour. Employee Relations, 25(6), 557-573.

Pathak, R.D., Budhwar, P.S., Singh, V. and Hannas, P. (2005). Best HRM practices and employees' psychological outcomes: a study of companies in Cyprus. South Asian Journal of Management, 12(4), 7-24.

Pfeffer, J. (1998). The Human Equation: Building Profits by Putting People First. Boston: Harvard Business Review Press.

Podsakoff, P.M., Mackenzie, S.B., Moorman, R.H. and Fetter, R. (1990). Transformational leader behaviors, and their effects on followers' trust in leader, satisfaction, and organisational citizenship behaviors. Leadership Quarterly, 1(2), 107-142.

Robinson, S.L. and Morrison, E.W. (1995). Psychological contracts and OCB: The effect of unfulfilled obligations on civic virtue behavior. Journal of Organizational Behavior, 16(3), 289-298.

Robinson, S.L. and Morrison, E.W. (2000). The development of psychological contract breach and violation: a longitudinal study. Journal of Organizational Behavior, 21(5), 525-546.

Roche, F., 2007. Review - One Foot out the Door. [Online] Available: http://www.judithmbardwick.com/files/review.html (April 29, 2010).

Rousseau, D.M. (1989). Psychological and Implied Contracts in Organizations. Employee Responsibilities and Rights Journal, 2(2), $121-139$.

Rousseau, D.M. and Greller, M.M. (1994). Human resource practices: Administrative contract makers. Human Resource Management, 33(3), $385-401$.

Sonnenberg, M. (2006). The Signalling Effect of HRM on Psychological Contracts of Employees: A multi-level perspective. Rotterdam: Erasmus Research Institute of Management (ERIM).

Statistics South Africa (2012). Quarterly Labour Force Report: Quarter 4, 2012. Pretoria: Statistics South Africa.

StatSoft. (2013). Statistica Version 11. [Online] Available: http://www.statsoft.com/support/download/installation-instructions (June 4, 2012).

Tausig, M. and Fenwick, R. (1999). Recession and Well-Being. Journal of Health and Social Behavior, 40(1), 1-16.

Theron, A.V.S. and Dodd, N.M. (2011). Organisational commitment in a post-merger situation. South African Journal of Economic and Management Sciences, 14(3), 333-345.

Turnley, W.H. and Feldman, D.C. (1999). The Impact of Psychological Contract Violations on Exit, Voice, Loyalty, and Neglect. Human Relations, 52(7), 895-922.

Watson, J., 2010. Psychological Recession: Alienating Employees and Hurting American Business. [Online] Available: http://www.aesthetictrends.com/monthly_updates/Summer2010/Summer2010JobFITFINAL.pdf (August 15, 2011). 